\title{
Study of the variables which influence the impregnation of globules, compressed tablets and tablet triturates used in homeopathy
}

\author{
Fernanda Santos de Souza ${ }^{1}$, Mayara Marin Pirolli', Eliana Elisabeth Diehl2,", Diva Sonaglio ${ }^{3}$
}

${ }^{1}$ Undergraduate Course of Pharmacy, Federal University of Santa Catarina, ${ }^{2}$ Laboratory of Homeopathic Pharmacotechnique, Department of Pharmaceutical Sciences, Center of Health Sciences, Federal University of Santa Catarina, ${ }^{3}$ Laboratory of Pharmacotechnique, Department of Pharmaceutical Sciences, Center of Health Sciences, Federal University of Santa

Catarina

\begin{abstract}
Globules, compressed tablets and tablet triturates are solid dosage forms used in homeopathy. Divergences can be noted between the preparation techniques described in official compendiums as well as those applied in homeopathic pharmacies. The difficulty associated with standardization of the impregnation of these dosage forms occurs due to the lack of detail provided for the techniques in the literature, leaving it up to each pharmacy to decide on the exact method of preparation. The objective was to optimize the impregnation technique, through investigating the variables that influence the impregnation of globules, compressed tablets and tablet triturates, applying the statistical tool of factorial design. The independent variables were the dosage form, percentage and type of impregnation and drying temperature, and the dependent variables were the mass gain, disintegration time, friability and hardness. For the globules, the greatest mass gain was for $10 \%$ impregnation and drying at $20{ }^{\circ} \mathrm{C}$. For the tablet triturates and compressed tablets the greatest mass gain was for $15 \%$ impregnation and there was no difference between the results obtained using simple and triple impregnation or different drying temperatures. The results can contribute to improving the final product quality, besides aiding in the establishment of standardized techniques for the official compendiums.
\end{abstract}

Uniterms: Homeopathic pharmacotechniques. Homeopathic vehicles. Homeopathy/impregnation methods. Homeopathy/globules. Homeopathy/tablet triturates. Homeopathy/compressed tablets.

Glóbulos, comprimidos e tabletes são formas farmacêuticas sólidas utilizadas em homeopatia. Constatamse divergências entre técnicas de preparação descritas nos compêndios oficiais, bem como em farmácias homeopáticas. A dificuldade de padronização na impregnação destas formas farmacêuticas também ocorre devido à falta de detalhamento das técnicas na literatura existente, deixando para cada farmácia a escolha de como executá-las. O objetivo foi otimizar a técnica de impregnação, através do estudo de variáveis que interferem na impregnação de glóbulos, comprimidos e tabletes, aplicando como ferramenta estatística planejamento fatorial. As variáveis foram forma farmacêutica, percentual e tipo de impregnação e temperatura de secagem, sendo o ganho de massa, tempo de desintegração, friabilidade e dureza as variáveis dependentes. Para os glóbulos, observou-se maior ganho de massa quando impregnados a $10 \%$ e secagem realizada a $20{ }^{\circ} \mathrm{C}$. Para os tabletes e comprimidos, constatou-se maior ganho de massa quando impregnados a $15 \%$, sendo que não houve diferença na impregnação simples ou tríplice nem nas diferentes temperaturas de secagem. Os resultados obtidos podem contribuir para a melhoria da qualidade do produto final, além de auxiliar no estabelecimento de técnicas padronizadas para os compêndios oficiais.

Unitermos: Farmacotécnica homeopática. Veículos homeopáticos. Homeopatia/métodos de embebição. Homeopatia/glóbulos. Homeopatia/tabletes. Homeopatia/comprimidos.

\footnotetext{
*Correspondence: E. E. Diehl. Laboratório de Farmacotécnica Homeopática, Departamento de Ciências Farmacêuticas, Centro de Ciências da Saúde, Universidade Federal de Santa Catarina, Campus Universitário, 88040-900

- Florianópolis - SC, Brasil. E-mail: elianadiehl@hotmail.com
} 


\section{INTRODUCTION}

Homeopathy is currently one of the fastest growing medical and pharmaceutical areas in Brazil, due, in particular, to the health policies that call for its incorporation in the Unified Health System (Brasil, 2006, 2010). It emerged in the XVIII and XIX centuries, created and developed by the German medical doctor Christian Friedrich Samuel Hahnemann. In homeopathy, the medicines are administered with preventive and therapeutic aims, according to the principle of similitude, based on the natural law of healing Similia similibus curantur or "like cures like".

Homeopathic treatment consists of seeking a medicine that provokes the totality of the symptoms presented by the patient. To this aim, a substance is administered which is able to produce symptoms similar to the disease and stronger than it in healthy, although sensitive, individuals during experimentation (nowadays in clinical trials), in order to stimulate the organism to react against the illness (Hahnemann, 2001).

In homeopathy, substances are diluted or potentialized by succussion and/or successive triturations, representing the dynamization process. These medicines, when used internally, can be dispensed in liquid dosage forms, as drops and single doses, or as solid dosage forms, such as globules, compressed tablets and tablet triturates. These dosage forms, through their impregnation, are used as a vehicle for the substances derived from the source material (Fontes, 2005).

Globules are small, white, slightly porous, homogeneous and regular spheres, almost inodorous and with a sweet taste. They are obtained industrially from sugar (sucrose) grains or mixture of sucrose and lactose (milk sugar) through multiple coatings, with median weights of $30 \mathrm{mg}$ (No. 3), $50 \mathrm{mg}$ (No. 5) and $70 \mathrm{mg}$ (No. 7). The inert compressed tablets have a discoid form and are obtained by compression of lactose, or a mixture of lactose and sucrose. The tablet triturates are smaller than compressed tablets and are of cylindrical form, being prepared by lactose molding in a tablet mold. Both are white, inodorous and with a slightly sweet taste (Farmacopeia Homeopática Brasileira, 1997).

The quality of a homeopathic medicine is dependent on, besides the inert starting materials, the techniques employed for its preparation. However, specific detailed references related to the validation or optimization of these pharmacotechnical procedures are not found in the literature. In Brazil, there are two official references for the preparation of homeopathic medicines (on the industrial or pharmacist level); however, there are divergences in relation to the methods described for the imbibition (referred to herein as impregnation) of the solid dosage forms. According to the second edition of the Brazilian Homeopathic Pharmacopeia (Farmacopeia Homeopática Brasileira, 1997), globules should be impregnated by the triple method, with $10 \%(\mathrm{~V} / \mathrm{m})$ of the active ingredient and the drying carried out in an oven at up to $50^{\circ} \mathrm{C}$. According to the fourth edition of the Manual of Technical Norms for Homeopathic Pharmacy (ABFH, 2007), the impregnation can be carried out by the simple or triple method and the percentage of active ingredient can vary from $2 \%(\mathrm{v} / \mathrm{m})$ to $5 \%(\mathrm{v} / \mathrm{m})$, the drying being carried out at ambient temperature or below $40{ }^{\circ} \mathrm{C}$. For tablet triturates and compressed tablets, the Brazilian Homeopathic Pharmacopeia (Farm. Hom. Bras., 1997) recommends impregnation of $10 \%(\mathrm{v} / \mathrm{m})$ and drying in an oven at up to $50{ }^{\circ} \mathrm{C}$. The Manual of Technical Norms for Homeopathic Pharmacy (ABFH, 2007) advises impregnation of $15 \%$ $(\mathrm{v} / \mathrm{m})$ and a drying temperature below $40{ }^{\circ} \mathrm{C}$.

In homeopathy, the problem of dosage can be approached quantitatively (proportion of solute:solvent) or through a dynamic focus that considers the potency, dynamization scale and administration frequency. According to Gomes (2008), "the different forms of pharmaceuticals dispensed for internal use permit a great variation of the medication dosage administered to the patient", when the quantitative proportion is considered. Thus, the different criteria of impregnation of solid forms, defined by the two official references in Brazil (Farmacopeia Homeopática Brasileira, 1997; ABFH, 2007), result in different dosages in relation to the medications in liquid form. Therefore, it is of interest to establish a standardization of the method of impregnation of solid forms used in homeopathy.

In this context, the objective of this study was to evaluate the influence of the variables which affect the impregnation of globules, compressed tablets and tablet triturates using factorial design. To this aim, the independent variables selected were the dosage form, the percentage of impregnation, the type of impregnation and the drying temperature, and the dependent variables were the mass gain, disintegration time, friability and hardness.

\section{MATERIAL AND METHODS}

\section{Material}

To carry out the tests the following materials were used: inert globules No. 5 (Laboratório Scharaibmann Ltda), inert tablet triturates (Laboratório Scharaibmann Ldta), inert compressed tablets (Laboratório Scharaibmann Ltda), 96\% hydrated ethanol obtained from cereals (Agro Industrial Tarumã Ltda.), alcohol solution (96\%) of methyl violet $1 \%(\mathrm{~m} / \mathrm{V})$, adjustable-volume pipette 
(Kacil;100 to $1000 \mu \mathrm{L}$ ), analytical balance (Gibertini E42S-B), oven (Fanem $315 \mathrm{SE}$ ), disintegration device (Nova Ética 301-AC), friabilometer (Nova Ética 300) and durometer (Nova Ética 298-AT).

\section{Methods}

\section{Preparation of globules}

On the analytical balance, 12 samples (in duplicate) of around $10 \mathrm{~g}$ of inert globules No. $5(50 \mathrm{mg})$ were weighed in an amber glass flask with a capacity of $60 \mathrm{~mL}$, where the impregnations were carried out with a solution of $1 \%(\mathrm{~m} / \mathrm{v})$ methyl violet.

The experiments carried out in relation to the globule dosage form involved the combination of the levels of the two variables shown in Table I (the formulation variable 'percentage of impregnation' and the process variable 'drying temperature') in a random form.

The impregnation of the inert globules was carried out using the method of triple impregnation only, defined by Diehl et al. (2008), which was considered to be the most appropriate despite requiring additional preparation time. Furthermore, even simple impregnation is not a commonly performed activity in homeopathic pharmacies in the municipality of Florianópolis, Santa Catarina State, Brazil.

For the samples impregnated at $3 \%(0.3 \mathrm{~mL})$ an automatic pipette adjusted to $1 / 3$ of the volume, that is, three portions of $0.1 \mathrm{~mL}$, was used. For the samples with an impregnation percentage of $5 \%(0.5 \mathrm{~mL})$, two portions of $0.16 \mathrm{~mL}$ followed by one of $0.18 \mathrm{~mL}$ were added. Finally, for the percentage of $10 \%(1 \mathrm{~mL})$, a volume of $0.33 \mathrm{~mL}$ was added twice and $0.34 \mathrm{~mL}$ was added once.

The dye solution was distributed over the walls of the flask, with circular movements. Between each addition of dye solution the flask was shaken for 1 minute and the samples were then dried. This drying was carried out for an hour at an ambient temperature of $20^{\circ} \mathrm{C}\left( \pm 2{ }^{\circ} \mathrm{C}\right)$, controlled by air conditioning and a dehumidifier, or in an oven maintained at $50{ }^{\circ} \mathrm{C}\left( \pm 2{ }^{\circ} \mathrm{C}\right)$.

Preparation of compressed tablets and tablet triturates.

Thirty-two samples (in duplicate) of around $10 \mathrm{~g}$ were weighed, that is, 16 for each of the two dosage forms, in amber flasks of $60 \mathrm{~mL}$, in which the impregnations were carried out. The formulation and process variables used in the carrying out of the experiments are described in Table II.

For the simple impregnations, the dye content was added $(1.0 \mathrm{~mL}$ and $1.5 \mathrm{~mL}$, for impregnations of $10 \%$ and $15 \%$, respectively) in a single step. For the triple impregnation at $10 \%, 1.0 \mathrm{~mL}$ divided into two portions of $0.33 \mathrm{~mL}$ and one of $0.34 \mathrm{~mL}$ was used. For the triple impregnation at $15 \%(1.5 \mathrm{~mL})$ the content was divided into three equal volumes of $0.5 \mathrm{~mL}$. The $1 \%$ methyl violet solution was distributed over the walls of the flask with circular movements followed by shaking of the flask for 1 minute and the drying of the samples occurred under the same conditions used for the globules, as described above.

\section{Characterization of the samples}

After impregnation and drying the samples were weighed again, and the difference between the initial mass and that obtained after impregnation and drying was obtained. The disintegration, friability and hardness tests were carried out as described in the Brazilian Pharmacopeia (Farm. Bras., 1988) for the compressed tablets.

TABLE I - Factors and levels of factorial design for inert globules

\begin{tabular}{lcccc}
\hline \multirow{2}{*}{ Variables } & \multirow{2}{*}{ Type } & Low $(-)$ & Intermediate $(0)$ & High $(+)$ \\
\cline { 3 - 5 } & & $3 \%$ & $5 \%$ & $10 \%$ \\
A- Percent of impregnation & Numerical & $20{ }^{\circ} \mathrm{C}$ & - & $50{ }^{\circ} \mathrm{C}$ \\
B- Drying Temperature & Numerical & &
\end{tabular}

TABLE II - Factors and levels of factorial design for compressed tablets and tablet triturates

\begin{tabular}{lccc}
\hline \multirow{2}{*}{ Variables } & \multirow{2}{*}{ Type } & Low $(-)$ & Hevel \\
\cline { 3 - 4 } & & Compressed Tablets $(+)$ & Tablet Triturates \\
\hline A- Dosage Form & Categorical & $10 \%$ & $15 \%$ \\
B- Percent of impregnation & Numerical & Simple & Triple \\
C- Form of impregnation & Categorical & $20^{\circ} \mathrm{C}$ & $50^{\circ} \mathrm{C}$ \\
D- Drying temperature & Numerical &
\end{tabular}


In order to determine the disintegration time, a system of baskets and tubes was moved vertically within the immersion liquid (water at $37^{\circ} \mathrm{C} \pm 1{ }^{\circ} \mathrm{C}$ ), with a constant frequency and specific trajectory.

The friability test consisted of weighing 20 units of the sample and submitting them to rotation $(20 \mathrm{rpm})$ in the friabilometer for 5 minutes. The samples were removed from the device, eliminating any dust residue from the surface with the aid of a brush, and weighed again. The difference between the initial and final masses represented the friability as a function of the percentage of powder loss.

The hardness was determined in a durometer, submitting the solid dosage forms to a force, sufficient to crush them, applied diametrically.

\section{Statistical design and analysis}

Two full factorial designs were prepared, one for the study of the globule dosage form (Design 1, Table I) and another for the compressed tablet and tablet triturate dosage forms (Design 2, Table II). The experiments were carried out in duplicate, in a random manner, totalizing 12 tests for Design 1 and 32 tests for Design 2. According to Table I, the factors (or independent variables) evaluated in the study of the globule dosage form were: A - percentage of impregnation of active ingredient: $3 \%, 5 \%$ and $10 \%$; and $\mathrm{B}$ - drying at ambient temperature $\left(20^{\circ} \mathrm{C}\right)$ and in an oven $\left(50^{\circ} \mathrm{C}\right)$.

The independent variables evaluated in Design 2 were: A - dosage form (compressed tablet and tablet triturate); $\mathrm{B}$ - percentage of impregnation of active ingredient: $10 \%$ and $15 \%$; C- type of impregnation (simple or triple); and D - drying temperature $\left(20^{\circ} \mathrm{C}\right.$ and $\left.50{ }^{\circ} \mathrm{C}\right)$.

In the two types of design, the responses (or dependent variables) of mass difference, disintegration time, friability and hardness were analyzed. The effect of each factor on the responses was calculated assuming a linear model with interaction between the factors, using the program Design Expert, version 8.0.4 (Stat Ease, Inc, MN, USA). The regression equation resulting from the factorial design is of the type:

$$
\begin{gathered}
Y=b_{0}+b_{1} A+b_{2} B+b_{3} C+b_{4} D+b_{12} A B+b_{13} A C+ \\
b_{14} A D+b_{23} B C+b_{24} B D+b_{34} C D
\end{gathered}
$$

where $Y$ is the response of the model, $b_{0}$ is the average of the values, $b_{1}, b_{2}, b_{3}, b_{4}$ are the coefficients of the main effects $(A, B, C, D), b_{12}, b_{13}, b_{14}, b_{23}, b_{24}, b_{34}$, are the coefficients of the interactions between two factors $(A B, A C$, $A D, B C, B D, C D$ ). Analysis of variance (ANOVA) was carried out for each response employing an error probability of $p \leq 0.05$. The terms which appear in the equation were determined by hierarchical analysis. The full factorial design provides sufficient degrees of freedom for the statistical discrimination between the main factors (A, B and $\mathrm{C})$, and the binary $(\mathrm{AB}, \mathrm{AC}$, and $\mathrm{BC})$ and ternary $(\mathrm{ABC})$ interactions (Montgomery, 2001).

\section{RESULTS AND DISCUSSION}

This study gives continuity to that published by Diehl et al. (2008), who analyzed the responses of mass difference and disintegration time for the impregnation of inert globules No. 7, which was the dosage form most commonly employed at that time in Florianópolis, Santa Catarina State, Brazil. Currently, in this municipality, there is a tendency to use globules No.5, as also reported by Rocha et al. (2000), as well as compressed tablets and tablet triturates. These three dosage forms constituted the study material in this research.

Factorial designs are used primarily to carry out screening of the significant factors, but they can also be used to model and refine the analysis (or process). The selection of the factors analyzed in the designs was based on data available in the literature (Brazilian Homeopathic Pharmacopeia and Manual of Technical Norms for Homeopathic Pharmacy), on current practices in homeopathic pharmacies in Florianópolis and also on a study previously carried out by Diehl et al. (2008).

The methyl violet dye solution was used as a visual indicator, considering the contrast provided by the coloring of the white solid dosage forms, thus enabling the organoleptic characteristics to be observed. According to Araújo et al. (2004) and the Manual of Technical Norms (ABFH, 2007), methyl violet dye is the most appropriate solution for the visual analysis of impregnated samples, showing behavior similar to the impregnation solution used in practice. In this study, no significant difference was observed for the color homogeneity of the samples (Figure 1). The choice of $96 \%$ hydrated ethanol obtained from cereals for the preparation of the dye solution at $1 \%$ was based on a study by Fontes et al. (2002), who showed that with the use of a solution with higher alcohol content a mass gain occurs in almost all of the impregnations, whereas on using a hydroalcoholic solution at $70 \%$ the opposite behavior is observed. This value differed from that of Diehl et al. (2008), who opted for $70 \%$.

All of the tests were carried out in duplicate, with the aim of estimating the experimental error and evaluating the statistical significance of the effects. In order for the results to be valid the duplicate must consist of an authentic repetition. In order to avoid the occurrence of statistical distortion of the results, the experiments were carried out in random order, so that atypical errors were not forced to 
(a)
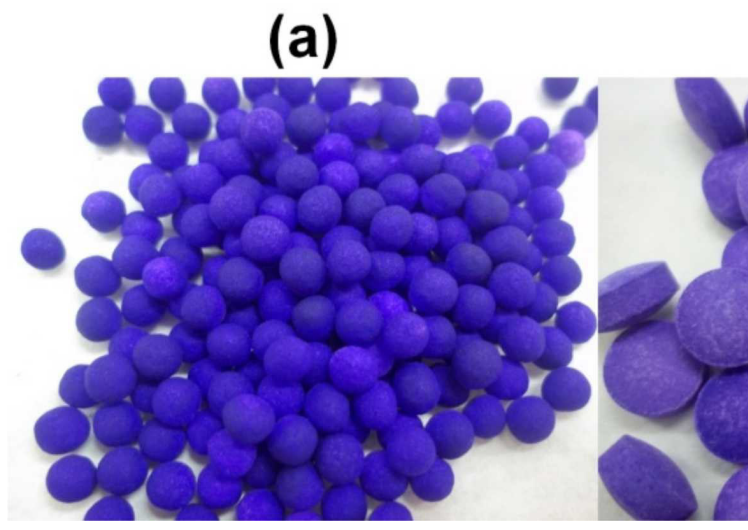

(b)

(c)

FIGURE 1 - a) Globules, b) compressed tablets, c) tablet triturates, impregnated with 1\% methyl violet dye solution.

be associated with certain combinations of levels (Neto, Scarminio, Bruns, 2001).

Different variables related to the method of impregnation of the inert globules, tablet triturates and compressed tablets were tested, considering the differences observed in the practices carried out at homeopathic pharmacies in Florianópolis, thus reflecting the lack of standardization. The variables selected were analyzed according to the responses obtain (mass difference, disintegration time, friability and hardness) providing evidence of their influence on the quality and characteristics of the final product.

\section{Globules}

One of the greatest obstacles found in the standardization of the method of impregnation of homeopathic globules is the number of variables involved in the process, which must be considered during the preparation of these pharmaceutical forms (Fontes et al., 2002). Furthermore, even though studies on the validation of methods for globule impregnation have been published (Rocha et al., 2000; Gutierrez, 2001; Fontes et al., 2002; Pozetti, Silva, Pizzolitto, 2002; Sartori et al., 2003; Araújo et al., 2004; Pinheiro, 2006; Diehl et al., 2008), the results reported are still not sufficient to verify the most adequate method for application in homeopathic pharmacies in the preparation of this form of medication.

In this study, the limit values for the responses obtained in Design 1 for the globule dosage form under different experimental conditions are shown in Table III.

The analysis of variance (ANOVA) of the factorial model for the responses mass difference and hardness are given in Table IV. Values for "Prob $>$ F" which are lower than or equal to $5 \%(p \leq 0.05)$ indicate that the terms are significant. The ANOVA for the factorial model selected gave a value of $p<0.05$ for the response mass difference, demonstrating that the model is significant, the model
TABLE III - Minimum, mean and maximum values for the responses related to the globules (Design 1)

\begin{tabular}{lccc}
\hline Response & Minimum & Mean & Maximum \\
\hline Mass Difference (g) & 0.0424 & 0.2255 & 0.4071 \\
$\begin{array}{l}\text { Disintegration Time } \\
\text { (min) }\end{array}$ & 1.33 & 1.55 & 1.83 \\
Friability (\%) & 0.03 & 0.59 & 2.49 \\
Hardness (Kgf) & 2.14 & 3.19 & 4.38 \\
\hline
\end{tabular}

for the response hardness having a value of $p=0.05$. The models for the responses friability and disintegration time were not significant. Diehl et al. (2008) also did not find significant results $(p=0.05)$ for the disintegration time in all factors analyzed.

TABLE IV - ANOVA for the factorial models of the responses mass difference and hardness related to the globules (Design 1)

\begin{tabular}{lcccc}
\hline \multirow{2}{*}{ Source } & \multicolumn{2}{c}{ Mass Difference } & \multicolumn{2}{c}{ Hardness } \\
\cline { 2 - 5 } & F Value & $\begin{array}{c}p \text { Value } \\
\text { Prob }>\text { F }\end{array}$ & F Value & $\begin{array}{c}p \text { Value } \\
\text { Prob }>\text { F }\end{array}$ \\
\hline Model & 7.66 & 0.0098 & 3.98 & 0.0525 \\
A & 9.00 & 0.0090 & 5.84 & 0.0273 \\
B & 4.97 & 0.0563 & 0.25 & 0.6312 \\
Lack of Fit & 0.27 & 0.7745 & 0.46 & 0.6530 \\
$\mathrm{R}^{2}$ & \multicolumn{2}{c}{0.74} & \multicolumn{2}{c}{0.60} \\
\hline
\end{tabular}

As shown in Table IV, for the response mass difference, factor (A) percentage of impregnation ( $p=0.009$ ) was considered significant, and factor (B) drying temperature $(p>0.05)$ did not show significance. The response mass difference increased with an increase in the percentage of impregnation (Figure 2), since a greater absorption of the impregnation solution by the inert globules occurred, a 
result also observed by Diehl et al. (2008). These results are similar to those observed by Fontes et al. (2002), who analyzed globules No. 7 using an impregnation percentage of $2 \%$ in a hydroalcoholic solution of $70 \%$. On comparing the results obtained with an increase in the drying temperature from $20^{\circ} \mathrm{C}$ to $50^{\circ} \mathrm{C}$, although the factor did not show significance, a slight reduction was observed in the mass difference with the increase in temperature. This may occur due to greater evaporation of the solvent used ( $96 \%$ alcohol obtained from cereals), in contrast to the results obtained by Diehl et al. (2008), who used a hydroalcoholic solution with a lower content (70\% ethanol), as did Gutierrez (2001), who indicated that a triple impregnation of $10 \%$ with methylene blue dye solution (in 70\% ethanol) was not efficient. Thus, the greatest mass difference occurred when the percentage of impregnation was $10 \%$ and the drying temperature was $20{ }^{\circ} \mathrm{C}$, as shown in Figure 2a.

According to Table IV, the response hardness was only influenced by factor (A) percentage of impregnation. It can be observed in Figure $2 b$ that for the percentages of impregnation of 3\% and 5\% there is no significant difference, but as this percentage increases to $10 \%$ there is a considerable reduction in this parameter. According to Ponçano (2006), the lower the quantity of sucrose (due to its dissolution when the percentage of impregnation increases) the less hard the globule. In general, globules must have sufficient hardness to resist breaking during handling, storage and transport; however, they must have characteristics which allow suitable disintegration after they are administered (Larocca, 2003). It was observed in this study that a percentage of impregnation higher than 5\% can adversely affect the integrity of the globule dosage form. However, the hardness was not altered by a change in the drying temperature, regardless of the percentage of impregnation.
Neither the Brazilian Homeopathic Pharmacopeia (Farmacopeia Homeopática Brasileira, 1997) nor the Manual of Technical Norms for Homeopathic Pharmacy (ABFH, 2007) recommends the hardness and friability tests for globules. Considering the results obtained in this study, particularly with regard to hardness, the inclusion of these quality parameters for globules in the official compendiums is suggested.

\section{Compressed tablets and tablet triturates}

The values obtained for the responses in Design 2 , for the dosage forms of compressed tablets and tablet triturates under the different experimental conditions, are given in Table $\mathrm{V}$.

The ANOVA of the factorial model for the responses which were significant (mass difference, disintegration time and friability) is given in Table VI. In this case only the model for the response hardness was not significant.

For the response mass difference, the variables (A) dosage form $(p<0.0001)$ and (B) percentage of impregnation $(p=0.0080)$ were shown to be significant (Table VI).

TABLE V - Minimum, mean and maximum values for the responses related to compressed tablets and tablet triturates (Design 2)

\begin{tabular}{lccc}
\hline Response & Minimum & Mean & Maximum \\
\hline Mass Difference(g) & -0.27 & 0.11 & 0.39 \\
$\begin{array}{l}\text { Disintegration Time } \\
\text { (min.) }\end{array}$ & 3.00 & 8.04 & 12.21 \\
Friability (\%) & 0.10 & 0.26 & 0.56 \\
Hardness (Kgf) & 4.58 & 8.05 & 11.06 \\
\hline
\end{tabular}

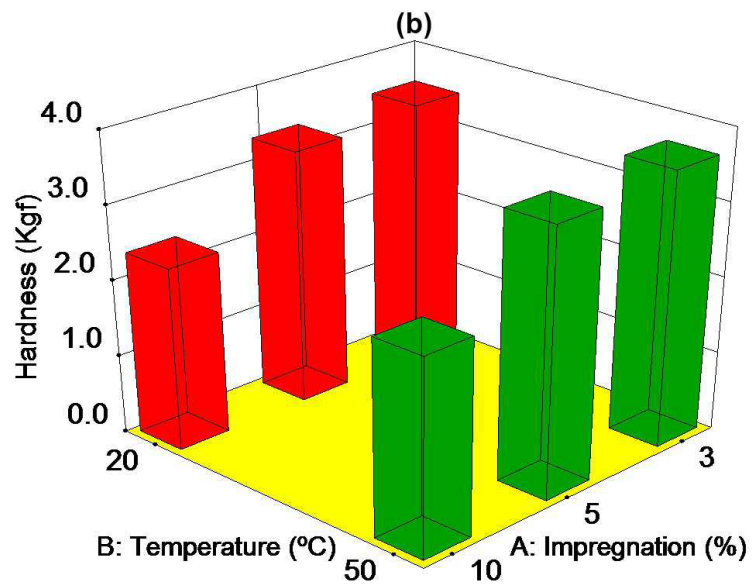

FIGURE 2 - Influence of temperature and percentage of impregnation on the responses: a) mass difference and b) hardness of the globules. 
TABLE VI - ANOVA for the factorial models of the responses mass difference, disintegration time and friability for the compressed tablets and tablet triturates (Design 2)

\begin{tabular}{lcccccc}
\hline \multirow{2}{*}{ Source } & \multicolumn{2}{c}{ Mass Difference } & \multicolumn{2}{c}{ Disintegration Time } & \multicolumn{2}{c}{ Friability } \\
\cline { 2 - 7 } & F Value & $\begin{array}{c}p \text { Value } \\
\text { Prob }>\text { F }\end{array}$ & F Value & $\begin{array}{c}p \text { Value } \\
\text { Prob }>\text { F }\end{array}$ & F Value & $\begin{array}{c}p \text { Value } \\
\text { Pro } \mathrm{b}>\mathrm{F}\end{array}$ \\
\hline Model & 15.55 & $<0.0001$ & 28.36 & $<0.0001$ & 5.85 & 0.0011 \\
$\mathrm{~A}$ & 49.32 & $<0.0001$ & 108.16 & $<0.0001$ & 19.97 & 0.0002 \\
$\mathrm{~B}$ & 8.30 & 0.0080 & 0.25 & 0.6225 & 1.63 & 0.2143 \\
$\mathrm{C}$ & 0.28 & 0.5994 & 0.13 & 0.7256 & 2.61 & 0.1190 \\
$\mathrm{D}$ & 1.40 & 0.2475 & 4.90 & 0.0355 & 0.040 & 0.8434 \\
Lack of Fit & 1.78 & 0.1522 & 1.02 & 0.4755 & 0.73 & 0.6873 \\
$\mathrm{R}^{2}$ & & 0.71 & & 0.81 & & \\
\hline
\end{tabular}

As the percentage of impregnation increased an increase in the mass difference occurred for both compressed tablets and tablet triturates (Figure 3), due to the absorption of the dye solution. However, the compressed tablets showed a greater mass gain in relation to the tablet triturates, the latter, in some cases, losing mass (negative value; Table $\mathrm{V}$ and Figure 3). This behavior occurred both for the simple and triple types of impregnation and for the drying at ambient temperature or in an oven. The differences between the two dosage forms under study occurred mainly because the compressed tablets have a more porous surface, while the tablet triturates have a smooth surface, resulting in a greater difficulty associated with the absorption of the impregnation solution. Furthermore, the excess of nonabsorbed dye solution solubilizes and leads to mass loss of the tablet triturates, leaving residues on the internal walls of the flasks, thus explaining the mass loss.

The significant factors for the response disintegration time were: (A) dosage form $(p<0.0001)$ and (D) drying temperature ( $p=0.0355)$ (Table VI). The higher the drying temperature the shorter the disintegration time both for the compressed tablets and tablet triturates (Figure 3). This behavior can be explained by the greater evaporation of the impregnation solution at a temperature of $50{ }^{\circ} \mathrm{C}$. However, the tablet triturates disintegrated in a time period almost twice as long as that observed for the compressed tablets, but still within the time recommended by the Brazilian Pharmacopeia (Farm. Bras. IV, 1988), that is, a maximum of 30 minutes. This may be due to the differences in the technique used to produce the two dosage forms, making the tablet triturates less permeable and thus more resistant to disintegration. According to Farhat (2007), the tablet triturates are produced industrially using the compression technique and have the adjuvant magnesium stearate in their composition. Thus, in this study the tablet triturates were not produced in accordance with the recommendations established in the Brazilian Homeopathic Pharmacopeia (Farmacopeia Homeopática Brasileira, 1997), i.e., that inert tablet triturates should be produced by lactose molding in a tablet mold, without the addition of adjuvants. The same behavior for the disintegration time of the tablet triturates was observed for the simple and triple impregnation types and for different percentages of impregnation (Figure 3 ).

The only factor which influences the response friability is (A) dosage form $(p=0.0002)$. According to the Brazilian Pharmacopeia (Farm. Bras. IV, 1988), a mass loss of lower than $1.5 \%$ is acceptable for compressed tablets, and (a)

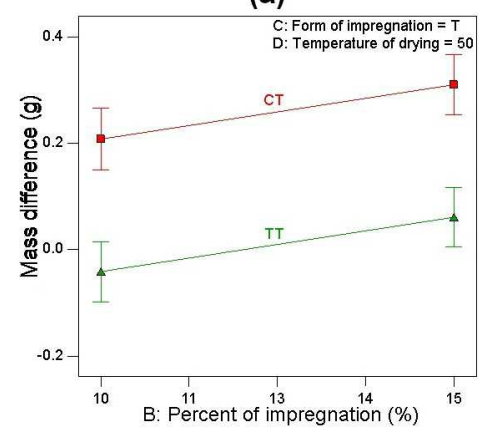

(b)

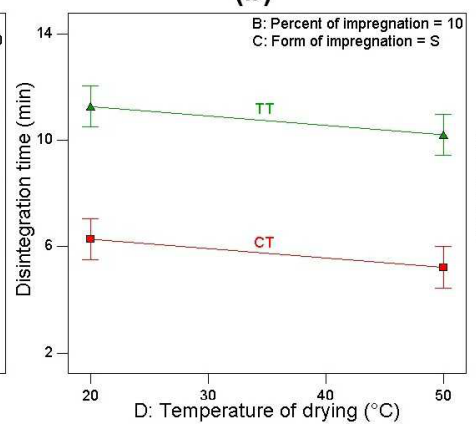

(c)

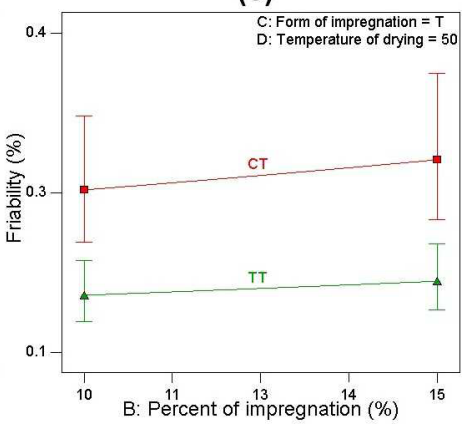

FIGURE 3 - a) Mass difference, b) disintegration time, c) friability of compressed tablets (CT) and tablet triturates (TT). 
all samples were below this level. According to the results presented herein, the compressed tablets had greater friability than the tablet triturates, for both types of impregnation, percentages of impregnation and drying temperatures. As previously suggested in relation to the disintegration time, this may also result from the differences in the processes used to produce these dosage forms, the industrialized tablet triturates being more resistant and having a smooth surface.

\section{CONCLUSIONS}

Many factors need to be considered in relation to preparing homeopathic medicines in solid dosage forms and the combination of these factors affects the final product quality.

Globules are currently the solid dosage form most dispensed at homeopathic pharmacies in Brazil (Fontes, 2005). These absorb a greater volume of solution when impregnated at $10 \%$ and dried at an ambient temperature of $20{ }^{\circ} \mathrm{C}\left( \pm 2{ }^{\circ} \mathrm{C}\right)$, besides showing better uniformity in terms of coloration. However, for the maximum level of impregnation a lower hardness was observed, which results in the possibility of the breaking of the globules.

In relation to the compressed tablets and tablet triturates, there were difficulties experienced in obtaining published information, since the literature on these homeopathic dosage forms is scarce. In practice, both dosage forms have greater uniformity of color and greater mass gain when impregnated at $15 \%$, and there was no difference when simple or triple impregnation methods were employed or the two different drying temperatures. However, it was noted that the compressed tablets appear to be the more appropriate dosage form since they showed a high mass gain and greater homogeneity than the inert tablet triturates obtained industrially, despite having the same composition. It was concluded that the dosage form of tablet triturates is less appropriate when compared with compressed tablets, since the former showed greater difficulty in absorbing the dye solution, requiring a long drying period, which inhibits their regular preparation at homeopathic pharmacies. This behavior can be explained by the use of industrialized tablet triturates, which are prepared by compression, and this contributes to the difficulty in standardizing the impregnation technique.

On comparing the globules with the compressed tablets and tablet triturates it was verified that the drying time for the globules was shorter, since they have a spherical shape providing a larger surface in contact with the air and the evaporation of alcohol in a more uniform manner (Farhat, 2007). Similarly, the disintegration occurred in a shorter time for the globules, due to the greater solubility of the sucrose in relation to the excipient lactose, used in compressed tablets and tablet triturates. Furthermore, the latter two forms have magnesium stearate in their composition, an inert adjuvant which acts as a hydrophobic lubricant, leading to a longer disintegration time (Larocca, 2003). Finally, the globules had lower hardness when compared with other dosage forms, which is probably a result of the preparation technique, besides differences in the composition and physical form.

The technical criteria for the standardization of the impregnation technique used for solid dosage forms must ensure the integrity, uniformity and quality of the homeopathic medicine. However, the official guidelines in Brazil do not describe in detail the procedures for this technique, leaving it up to each homeopathic pharmacy to decide on the way to proceed, resulting in difficulties associated with standardization and adversely affecting product quality.

In September 2011 the third edition of the Brazilian Homeopathic Pharmacopoeia (Farmacopeia Homeopática Brasileira, 2011) was published, which includes some updates in relation to the second edition, particularly with regard to the preparation of solid dosage forms. These changes, however, do not compromise the methodology and the results of this study, since these considered the above-mentioned new guidelines.

This study was able to identify the factors which influence the impregnation of homeopathic solid dosage forms and their magnitude. The results obtained can contribute to improving the final product quality, besides aiding the establishment of standardized techniques for the official compendiums.

\section{ACKNOWLEDGEMENTS}

The authors are grateful to the pharmacist Ângelo Fiamoncini, for providing all of the inert ingredients used to carry out the experiments; to Prof. Flávio Henrique Reginatto and Simone Gonçalves Cardoso of the Pharmaceutical Sciences Department at the Federal University of Santa Catarina (UFSC), for making the Pharmacognostic and Quality Control Laboratories available; and to Prof. Marcos Antônio Segatto Silva for valuable contributions in the discussion of the results. The authors also thank Dr. Siobhan Wiese for revising the manuscript.

\section{REFERENCES}

ASSOCIAÇÃO BRASILEIRA DE FARMACÊUTICOS HOMEOPATAS. ABFH. Manual de normas técnicas para farmácia homeopática. 4.ed. São Paulo: ABFH, 2007. p.10.8-10.19, 13.7-13.8. 
ARAÚJO, T.L.; MAZZI, J.L.; CHAUD, M.V.; GUTIERREZ, M.A.; FONTES, O.L. Validação de técnicas e métodos de impregnação de glóbulos homeopáticos. Cult. Homeop., v.9, n.2, p.8-12, 2004.

BRASIL. Portaria n.971, 3 maio 2006. Aprova a Política Nacional de Práticas Integrativas e Complementares (PNPIC) no Sistema Único de Saúde. Diário Oficial da União, Brasília, n.84, 4 maio 2006. Seção 1, p.20-25.

BRASIL. Portaria n.4217, 28 dez 2010. Aprova as normas de financiamento e execução do Componente Básico da Assistência Farmacêutica. Diário Oficial da União, Brasília, n.249, 29 dez 2010. Seção 1, p.72-74.

DIEHL, E.L.; SONAGLIO, D.; LIMA, N.F.; BACKES, S. Estudo dos fatores impregnação e secagem nas características de glóbulos utilizados em homeopatia. Braz. J. Pharm. Sci., v.44, n.1, p.143-150, 2008.

FARHAT, F.C.L.G. Validação do método de impregnação de tabletes e comprimidos homeopáticos. In: MOSTRA ACADÊMICA UNIMEP 5, 2007. Piracicaba. Anais Piracicaba: UNIMEP, 2007. p. 6.

FARMACOPEIA BRASILEIRA. 4.ed. São Paulo: Atheneu, 1988. Part 1.p.V.1.3-V.1.4.1.

FARMACOPEIA HOMEOPÁTICA BRASILEIRA. 2.ed. São Paulo: Atheneu, 1997. p.XII.2-XII.6, XV.17-XV.18.

FARMACOPEIA HOMEOPÁTICA BRASILEIRA. 3.ed. Brasília: ANVISA, 2011. Available at: <http://www.anvisa. gov.br/farmacopeiabrasileira/conteudo/3a_edicao.pdf $>$. Accessed on: 15 Oct. 2011.

FONTES, O.L. Farmácia homeopática - teoria e prática. 2.ed. Barueri: Manole, 2005. 354 p.

FONTES, O.L.; GUTIERREZ, M.A.; KASAMA, Y.; MAZZI, J.L. Variação do peso de glóbulos após a impregnação com solução de etanol a 70\%. Informativo ABFH, n.28, p.6-8, 2002.

GUTIERREZ, M.A.; Validação da técnica de impregnação de glóbulos homeopáticos. Rev. Homeop., v.66, n.2, p.27-35, 2001.

GOMES, A. Dose e formas farmacêuticas, correlação com os medicamentos líquidos. Informativo ABFH, n.50, p.4-5, 2008.
HAHNEMANN, S. Organon da arte de curar. 6.ed. São Paulo: Robe Editorial, 2001. 248 p.

LAROCCA, L.R.V. Comparação farmacotécnica entre comprimidos obtidos a partir de trituração e comprimidos obtidos por impregnação. São Paulo, 2003. $73 \mathrm{f}$. [Monograph of Conclusion (Specialization in Homeopathy) - Paulista School of Homeopathy].

MONTGOMERY, D.C. Design and analysis of experiments. 5.ed. New York: Wiley \& Sons, 2001. 707 p.

NETO, B.B.; SCARMINIO, I.S.; BRUNS, R.E. Planejamento e otimização de experimentos. 2.ed. Campinas: Editora da UNICAMP, 2001. 299 p.

PINHEIRO, M.S. Estudo da uniformidade de dose por conteúdo na impregnação de glóbulos. Rio de Janeiro, 2006. 131 p. [Dissertação de Mestrado. Faculdade de Farmácia. Universidade Federal do Rio de Janeiro].

PONÇANO, G.L. A importância da validação e das variações no processo de impregnação de glóbulos homeopáticos. São Paulo, 2006. 24 f. [Monograph of Conclusion (Specialization in Homeopathy) - Institute of Homeopathic Culture].

POZETTI, G.L.; SILVA, R.F.P.; PIZZOLITTO, E.L. Técnicas de impregnação de glóbulos homeopáticos: análise laboratorial. Rev. Racine, v.66, p.3-8, 2002.

ROCHA, L.; AFONSO, C.; LUNA, I.S.; SÁ, I.M.; Otimização da metodologia para impregnação de glóbulos aplicada a farmácias homeopáticas. Homeop. Bras, v.6, n.2, p.77-81, 2000 .

SARTORI, A.V.; DA SILVA, C.E.F.; FERNANDES, C.R.; PONTES, L.M.; BRASIL, L.A.; TEIXEIRA, W.G.; FUTURO, D.O. Avaliação do aspecto e da desagregação de glóbulos impregnados em diferentes métodos e em diferentes proporções. In: IV CONGRESSO BRASILEIRO DE FARMÁCIA HOMEOPÁTICA, 4. João Pessoa, 2003. Resumos. São Paulo: ABFH, 2003. p.16.

Received for publication on $23^{\text {rd }}$ October 2011 Accepted for publication on $30^{\text {th }}$ May 2012 
